\title{
Role of apolipoprotein E polymorphism as a prognostic marker in traumatic brain injury and neurodegenerative disease: a critical review
}

\author{
Tanmoy Kumar Maiti, MCh, Subhas Konar, MCh, Shyamal Bir, MD, PhD, Piyush Kalakoti, MD, \\ Papireddy Bollam, MD, and Anil Nanda, MD, MPH
}

Department of Neurosurgery, LSU Health Shreveport, Louisiana

\begin{abstract}
OBJECT The difference in course and outcome of several neurodegenerative conditions and traumatic injuries of the nervous system points toward a possible role of genetic and environmental factors as prognostic markers. Apolipoprotein $\mathrm{E}$ (Apo-E), a key player in lipid metabolism, is recognized as one of the most powerful genetic risk factors for dementia and other neurodegenerative diseases. In this article, the current understanding of APOE polymorphism in various neurological disorders is discussed.

METHODS The English literature was searched for various studies describing the role of APOE polymorphism as a prognostic marker in neurodegenerative diseases and traumatic brain injury. The wide ethnic distribution of $A P O E$ polymorphism was discussed, and the recent meta-analyses of role of APOE polymorphism in multiple diseases were analyzed and summarized in tabular form.
\end{abstract}

RESULTS Results from the review of literature revealed that the distribution of APOE is varied in different ethnic populations. $A P O E$ polymorphism plays a significant role in pathogenesis of neurodegeneration, particularly in Alzheimer's disease. $A P O E \varepsilon 4$ is considered a marker for poor prognosis in various diseases, but APOE $\varepsilon 2$ rather than APOE $\varepsilon 4$ has been associated with cerebral amyloid angiopathy-related bleeding and sporadic Parkinson's disease. The role of $A P O E$ polymorphism in various neurological diseases has not been conclusively elucidated.

CONCLUSIONS Apo-E is a biomarker for various neurological and systemic diseases. Therefore, while analyzing the role of $A P O E$ polymorphism in neurological diseases, the interpretation should be done after adjusting all the confounding factors. A continuous quest to look for associations with various neurological diseases and wide knowledge of available literature are required to improve the understanding of the role of APOE polymorphism in these conditions and identify potential therapeutic targets.

http://thejns.org/doi/abs/10.3171/2015.8.FOCUS15329

KEY WORDS apolipoprotein E; Alzheimer's disease; traumatic brain injury; neurodegenerative disease

$\mathrm{T}$ HE limited effectiveness of available interventions for neurodegenerative diseases has led researchers to focus on identifying genetic and modifiable predisposing factors that may be useful in prognosis as well as in developing possible therapeutic targets. Alteration of lipid metabolism has been implicated in various neurodegenerative diseases. Apolipoprotein E (Apo-E), a glycoprotein, plays a major role in the redistribution of cholesterol from cells during membrane synthesis, neuritic extension, growth, and repair. ${ }^{5,18,48,56,69}$ In various cell lines, Apo-E3 has been shown to increase growth and branching of neurites, whereas Apo-E4 was found to have an opposite effect. ${ }^{5,48}$ These associations, however, are not consistent in several similar diseases, and their prevalence varies among different ethnic populations. Research over the last 3 decades has revealed the importance of variation in the promoter regions apart from the traditional polymorphisms of $\varepsilon 2, \varepsilon 3$, and $\varepsilon 4$. The evolving knowledge has paved the way for a novel therapeutic target. In this article, we discuss the current understanding of the role of $A P O E$ polymorphism as a prognostic marker in traumatic brain injury (TBI) and other neurodegenerative conditions.

ABBREVIATIONS $A \beta=$ amyloid $\beta$ protein; $A D=$ Alzheimer's disease; $A L S=$ amyotrophic lateral sclerosis; $A P O E=$ apolipoprotein $E ;$ CAA = cerebral amyloid angiopathy; GOS = Glasgow Outcome Scale; ICH = intracerebral hemorrhage; PD = Parkinson's disease; SAH = subarachnoid hemorrhage; TBI = traumatic brain injury.

SUBMITTED July 1, 2015. ACCEPTED August 4, 2015.

INCLUDE WHEN CITING DOI: 10.3171/2015.8.FOCUS15329. 


\section{Apolipoprotein E Structure and Its Biophysical Properties}

Apolipoprotein E is a polymorphic 299-amino acid protein (molecular weight 34,200). ${ }^{38}$ The 3 common isoforms, Apo-E2, Apo-E3, and Apo-E4, are encoded by 3 alleles $(\varepsilon 2, \varepsilon 3, \varepsilon 4)$ of the same gene on chromosome 19 . Therefore, 3 homozygous ( $A P O E \varepsilon 2 / \varepsilon 2$, $\varepsilon 3 / \varepsilon 3$, and $\varepsilon 4 / \varepsilon 4)$ and 3 heterozygous ( $A P O E \varepsilon 3 / \varepsilon 2, \varepsilon 4 / \varepsilon 3$, and $\varepsilon 4 / \varepsilon 2)$ genotypes can occur in humans. The $A P O E \varepsilon 3$ allele is the most common form $(70 \%-80 \%)$, followed by APOE $\varepsilon 4$ $(10 \%-15 \%)$ and $A P O E$ \& $2(5 \%-10 \%){ }^{38}$

Apo-E3 has cysteine at 112 and arginine at 158 positions, whereas Apo-E4 has arginine and Apo-E2 has cysteine at both positions. Although the existence of E5 (further divided into E5f and E5s based on fast and slow migration in SDS-PAGE) and E7 isoforms is known, ${ }^{81}$ their present roles are not well defined. The polymorphism affects 2 key properties of Apo-E: domain interaction and protein stability or molten globule (stable folded intermediate of unstable unfolded protein) formation. Apo-E2 is the most stable isoform, followed by Apo-E3 and Apo-E4, ${ }^{4,45}$ and the isoforms are prone to molten globule formation in the reverse order. The APOE genotype is an important determinant of plasma and CSF Apo-E and lipid levels. The $A P O E$ \&2 allele is associated with high concentrations of Apo-E, while the $A P O E \& 4$ allele is associated with lower Apo-E levels. ${ }^{68}$ It is generally speculated that the enhanced instability of Apo-E4 leads to altered intradomain interactions, increased susceptibility to proteolysis, increased lipid and membrane binding, membrane disruption, and translocation across membranes. There are 2 structural domains in Apo-E: a 22-kD amino-terminal domain containing the low-density lipoprotein receptor binding region and a 10-kD carboxyl-terminal domain containing the major lipid-binding region. ${ }^{1,79}$ In Apo-E4, arginine-112 induces arginine-61 into a characteristic conformation, which may constitute a potential therapeutic target. ${ }^{39}$

\section{Ethnic Variation of APOE Polymorphism}

The APOE $\varepsilon$ alleles show a peculiar distribution throughout the world. The APOE $\varepsilon 3$ allele is the most frequent in all human societies. Corbo and Scacchi ${ }^{10}$ found that $A P O E \& 3$ seems to be more prevalent in populations with a long-established agricultural economy, such as those of the Mediterranean basin, where the allele frequency is $0.849-0.898$. On the other hand, $A P O E \varepsilon 4$ can be considered as an ancestral allele, with higher frequency in Pygmies (0.407), Khoi San (0.370), Papuans (0.368), and Native Americans (0.280). The frequency of the APOE $\varepsilon 2$ allele fluctuates with no apparent pattern $(0.145-0.02)$ and is absent in Native Americans and very uncommon $(<1 \%)$ in southern Europeans, according to populationbased studies. ${ }^{10,64,68,71}$ Interestingly, the pooled data show that $A P O E \& 3$ is prevalent in European and Asian populations and $A P O E \& 4$ is markedly higher in Oceanians and Africans (Table 1). ${ }^{10}$

\section{Role of $A P O E$ in Dementia $A P O E$ in AD}

The association of overrepresentation of $A P O E \varepsilon 4$ and
TABLE 1. Ethnic distribution of APOE polymorphism*

\begin{tabular}{lrrcc}
\hline \multirow{2}{*}{ Ethnicity } & \multirow{2}{c}{$\mathrm{N}$} & \multicolumn{3}{c}{ APOE Allele } \\
\cline { 3 - 5 } African & 1618 & 0.072 & 0.685 & 0.240 \\
\hline European & 24,262 & 0.068 & 0.813 & 0.119 \\
\hline Asian & 2938 & 0.075 & 0.816 & 0.109 \\
\hline Native American & 1045 & 0.008 & 0.796 & 0.195 \\
\hline Oceanian & 285 & 0.099 & 0.599 & 0.302 \\
\hline
\end{tabular}

* Based on Corbo and Scacchi. ${ }^{10}$

underrepresentation of $A P O E \varepsilon 2$ with sporadic and familial early- and late-onset Alzheimer's disease (AD) has been widely discussed. However, ethnic variation exists with respect to the magnitude of association. In Caucasians, the frequency of the $\varepsilon 4$ allele has been found to be increased from approximately $14 \%$ in controls to around $40 \%$ in the $\mathrm{AD}$ population in both the sporadic and familial forms of the disease. ${ }^{40,54}$ The risk increased from $20 \%$ when no APOE \&4 alleles were present to $90 \%$ when 2 copies of the $A P O E \& 4$ allele were present in another study. ${ }^{12}$ The $A P O E \& 4$ allele was shown to exert the worst effect on AD between the ages of 60 and 79 years. ${ }^{17}$ It was associated with more rapid memory decline in individuals without dementia ${ }^{13}$ and preclinical memory impairment in asymptomatic middle-aged individuals. ${ }^{8} A P O E \varepsilon 4$ also carried an increased risk for AD following trauma ${ }^{23}$ resulting from increased accumulation of $\mathrm{A} \beta{ }^{83}$ Similar findings were noted in boxers, where those possessing an APOE $\varepsilon 4$ allele had more severe cognitive deficits than those with no $A P O E \varepsilon 4$ alleles. ${ }^{30}$ The presence of herpes simplex virus type 1 in combination with an $A P O E \& 4$ allele was found to be a strong risk factor for AD. ${ }^{28}$ Long-term survivors of human immunodeficiency virus (HIV) infection with the $A P O E \& 4$ allele were found to be at higher risk for $\mathrm{AD}$, and gene-virus interactions were postulated to speed AD development. ${ }^{11}$ On the other hand, $A P O E$ \&2 alleles were associated with a delayed age of onset of $\mathrm{AD},{ }^{57,78}$ even in carriers of $A P P$ mutations. ${ }^{69}$ These findings suggest that a protective role is conferred by $A P O E \varepsilon 2$.

The pathological association seems multifactorial. The association of $A P O E$ with amyloid plaque density is more conclusively established ${ }^{52}$ than the association with density of neurofibrillary tangles, ${ }^{62}$ although many other reports have raised questions regarding these observations. ${ }^{6,43}$ It is hypothesized that the APOE \&4 allele enhances the progression of cerebral amyloid angiopathy (CAA), possibly via diminished clearance of amyloid $\beta(A \beta),{ }^{82}$ which may be an important pathophysiological mechanism in development of AD. APOE $\varepsilon 4$ had a dose-dependent relationship with CSF levels of A $\beta 42$, but not tau (A $\beta 42$ and tau are the 2 most important CSF biomarkers of AD with a decrease in former and increase in later is seen in AD) ${ }^{19}$ The presence of $A P O E \& 4$ was seen associated with dosedependent greater risk of hippocampal volume loss and a greater rate of atrophy even before the clinical presentation. The marked reduction in temporal cortical and hippocampal choline acetyltransferase activity ${ }^{3}$ and reduction of acetylcholinesterase-positive cell density in the nucleus basalis of Meynert and the diagonal band of Broca ${ }^{53}$ in 
patients with $A P O E \& 4$ may also predispose them to the development of $\mathrm{AD}$. The reduced antioxidant activity and impaired neuronal metabolism in individuals with the $A P O E \& 4$ allele may subject them to added risk. In a recent meta-analysis of 14 studies published from 1996 to 2014 seeking the association of $A P O E \varepsilon 4$ with a neuroimaging marker of $\mathrm{AD}$, the authors concluded that $A P O E \varepsilon 4$ was associated with atrophic hippocampal volume $(p=0.007)$ and increased cerebral amyloid deposition $(p=0.0006)$ and decreased cerebral metabolism, especially in the right middle frontal gyrus ${ }^{36}$ (Table 2).

Nevertheless, polymorphism at the 112 and 158 positions does not seem to be the only explanation of the variable response. Researchers have found polymorphisms in the promoter region of $A P O E$ leading to variable expression of Apo-E, therefore modulating the risk of developing $\mathrm{AD}$; the $-491 \mathrm{~A} / \mathrm{T}$ promoter polymorphism has been studied more extensively than the $-219 \mathrm{~T} / \mathrm{G}$ (Th1/E47cs), $+113 \mathrm{G} / \mathrm{C}$, and $-427 \mathrm{~T} / \mathrm{C}$ polymorphisms. ${ }^{34}$

\section{$A P O E$ in Non-AD Dementias}

The association of APOE polymorphism and other dementias is less well studied, and the results are more variable. Hardy et al. ${ }^{25}$ noticed a strong association between the $A P O E \& 4$ allele and $\mathrm{AD}$ and no association between the APOE $\varepsilon 4$ allele and Parkinson's disease (PD). Senile
Lewy body dementia was associated with a frequency of the $\varepsilon 4$ allele that was intermediate between that of $\mathrm{AD}$ and that of PD. Egensperger et al..$^{15}$ did not find the APOE $\varepsilon 4$ allele to be a risk factor that influences the development of $\mathrm{AD}$ lesions in patients with PD. However, the relationship seems to be stronger in AD and other dementias developing after TBI. Tang et al. observed a 10 -fold increase in the risk of $\mathrm{AD}$ among patients who were $A P O E$ \& 4 carriers and had a history of TBI. ${ }^{72}$ Luukinen et al. found that fall-related TBI predicted earlier onset of dementia in $A P O E \varepsilon 4$ carriers. ${ }^{37}$ The frequency of the $A P O E \varepsilon 4$ allele has been found to be increased in vascular dementia as well. ${ }^{51}$ Interestingly, the $A P O E \varepsilon 2 / \varepsilon 3$ genotype has been associated with a significantly earlier age of onset of Huntington's disease, ${ }^{31}$ and $A P O E$ \&2/ع2 has been associated with frontotemporal dementia, whereas $A P O E \varepsilon 4$ was not found to have any such association. ${ }^{75}$

\section{APOE and Head Injury}

The possible role of $A P O E$ polymorphism in predicting the outcome after TBI has drawn significant attention among researchers in last 2 decades. However, results varied here as well. Presence of the $A P O E \& 4$ allele has been suggested in various clinical studies to have a negative effect on outcome following closed head injury, ${ }^{18}$ but one of the largest studies (by Teasdale et al..$^{73}$ involving 1094 patients) revealed that $36 \%$ of $A P O E \varepsilon 4$ carriers had

TABLE 2. Summary of available meta-analyses on role of $A P O E$ polymorphism in various diseases

\begin{tabular}{|c|c|c|c|}
\hline Authors \& Year & Disease & Population & Comment \\
\hline Xin et al., 2010 & $A D$ & $\begin{array}{l}40 \text { studies (pts: 9662; con- } \\
\quad \text { trols: } 9696)\end{array}$ & $\begin{array}{l}\text {-491A/T polymorphism (AA vs AT + TT: OR 1.49) \& -219T/G polymorphism (TT vs } \\
\text { TG + GG: OR 1.30) showed significant association w/ AD susceptibility. }\end{array}$ \\
\hline $\begin{array}{l}\text { Sadigh-Eteghad et } \\
\quad \text { al., } 2012\end{array}$ & $A D$ & $\begin{array}{l}21 \text { studies (pts: } 1480 ; \text { con- } \\
\quad \text { trols: } 6777)\end{array}$ & $A P O E \varepsilon 4$ allele increases risk of sporadic late-onset $A D(p<0.001$, OR 3.98$)$. \\
\hline Liu et al., 2015 & $A D$ & $\begin{array}{l}14 \text { cross-sectional studies }(n \\
=1628) \text { comparing } w / \text { neu- } \\
\text { roimaging marker of } A D\end{array}$ & $\begin{array}{l}\text { APOE \&4 carrier status was associated w/ atrophic hippocampal volume }(p=0.007) \& \\
\text { increased cerebral amyloid PET tracer }(p=0.0006) \text {. }\end{array}$ \\
\hline Verpillat et al., 2002 & FTD & $\begin{array}{l}10 \text { cross-sectional studies } \\
\text { (pts: } 364 \text {; controls: } 2671 \text { ) }\end{array}$ & $\begin{array}{l}\text { Significant increase of } \varepsilon 2 \text { allele frequency in pts (OR [ } \varepsilon 2 \text { vs } \varepsilon 3] 2.01, p=0.04) \text {. No } \\
\text { correlation } w / A P O E \varepsilon 4 \text {. }\end{array}$ \\
\hline Zhou et al., 2008 & $\mathrm{TBI}$ & 14 studies $(n=2527)$ & $\begin{array}{l}A P O E \varepsilon 4 \text { allele is not associated } w / \text { initial severity of brain injury following TBI but is } \\
\text { associated } w / \text { increased risk of poor long-term outcome at } 6 \text { mos after injury (RR } \\
\text { 1.36). }\end{array}$ \\
\hline Zeng et al., 2014 & $\mathrm{TBI}$ & $\begin{array}{l}13 \text { cohort studies (TBI w/ } \\
\text { APOE } \varepsilon 4: 662 ; \mathrm{TBI} \text { w/0 } \\
\text { APOE } \varepsilon 4: 1614)\end{array}$ & $\begin{array}{l}\text { TBI pts w/ APOE } \varepsilon 4 \text { had a worse prognosis in Asian populations }(p=0.046) \text { but not } \\
\text { in Caucasian populations }(p=0.120) \& \text { in severe TBI }(p=0.020) \text { but not in other } \\
\text { grades of TBI (all } p>0.05) \text {. }\end{array}$ \\
\hline Sudlow et al., 2006 & $\begin{array}{l}\mathrm{IS}, \mathrm{ICH} \\
\text { SAH }\end{array}$ & IS: 26; ICH: 8; SAH: 3 & $\begin{array}{l}\text { APOE } \varepsilon 4 \text { significantly associated } w / \text { IS (OR 1.11, } p=0.03) \& \text { SAH (OR 1.42) but not w/ } \\
\text { ICH. APOE \&2 was associated w/ ICH (OR 1.32, } p=0.04) \text {. }\end{array}$ \\
\hline Schilling et al., 2013 & CVD & $\begin{array}{l}42 \text { studies }(n=29,965) \text { APOE } \\
\text { genotype \& MRI markers } \\
\text { of CVD }\end{array}$ & $\begin{array}{l}A P O E \varepsilon 4 \text { was associated w/ increasing white matter hyperintensity burden \& pres- } \\
\text { ence of cerebral microbleeds. APOE } \varepsilon 2 \text { was associated w/ increasing white matter } \\
\text { hyperintensity load \& risk of brain infarct. }\end{array}$ \\
\hline Zhang et al., 2014 & $\mathrm{ICH}$ & $\begin{array}{l}11 \text { case-control studies }(6 \\
\text { in Asian population; } 5 \text { in } \\
\text { Caucasian) (cases: } 1238 \text {; } \\
\text { controls: } 3575 \text { ) }\end{array}$ & $\begin{array}{l}\text { ICH cases had a significantly higher frequency of } A P O E \varepsilon 4 \text { allele }(O R 1.42, p<0.001) \\
\text { (OR } 1.52 \text { for Asians, } 1.34 \text { for Caucasians); } A P O E \varepsilon 2 \text { not different from } A P O E \varepsilon 3 \text {. }\end{array}$ \\
\hline Govone et al., 2014 & & Cases: 4249; controls: 10,397 & $A P O E \varepsilon 4$ allele was not associated w/ significantly increased disease risk. \\
\hline $\begin{array}{l}\text { Schürhoff et al., } \\
2003\end{array}$ & & $\begin{array}{l}14 \text { studies (cases: } 1949 \\
\text { controls: } 2354)\end{array}$ & APOE polymorphism did not have any association w/ incidence of schizophrenia. \\
\hline
\end{tabular}

$\mathrm{CVD}=$ cerebrovascular disease $; \mathrm{FTD}=$ frontotemporal dementia; IS = ischemic stroke; pts = patients. 
an unfavorable outcome at 6 months' follow-up compared with $33 \%$ of patients who did not carry this allele ( $\mathrm{p}=$ 0.23 ). However, children and young adults under 15 years of age with the $\varepsilon 4$ allele had less favorable outcomes. ${ }^{73}$ Worse outcome in children has been observed by other researchers as well. ${ }^{7}$ The poorer cognitive outcome after TBI has been established in several studies in neuropsychological testing. Nevertheless, several groups of authors have expressed doubt about the correlation. ${ }^{42,49,56}$ In a detailed neuropsychological assessment of 90 adult patients with mild and moderate TBI at 6-month followup, investigators found no effect of $A P O E \varepsilon 4$ allele poor outcome. ${ }^{9}$ Some studies have even revealed that $\varepsilon 4$ carriers performed better on measures of attention, executive functioning, and episodic memory encoding than do noncarriers. ${ }^{24}$ No significant associations were found between $A P O E \& 4$ status and the Sickness Impact Profile-68 (SIP-68) and Community Integration Questionnaire (CIQ) results. Diaz-Arrastia et al. found that $A P O E \varepsilon 4$ was not associated with an unfavorable outcome (as indicated by GOS-E [Extended Glasgow Outcome Scale] scores), although they did find an association between APOE $\varepsilon 4$ and late-onset posttraumatic seizure. ${ }^{14}$

In a meta-analysis of 14 eligible cohort studies between January 1993 and October 2007 including a total of 2527 participants (736 with and 1791 without the APOE \&4 allele) suggested that although the $A P O E$ \&4 allele does not influence the initial severity of TBI, it increases the risk of poor long-term outcome after TBI as measured by the Glasgow Outcome Scale (GOS) or GOS-E score at 6 months after injury. ${ }^{87}$ The latest meta-analysis by Zeng et al. ${ }^{84}$ in 2014, comprising 13 cohort studies (662 TBI patients with and $1614 \mathrm{TBI}$ patients without $A P O E \varepsilon 4)$, concluded that the $A P O E \varepsilon 4$ allele was associated with a poor prognosis in TBI patients (OR 0.68, $\mathrm{p}=0.027)$. Subgroup analysis by ethnicity indicated that TBI patients with $A P O E \& 4$ had a worse prognosis than those with $A P O E$ $\varepsilon 4$ in Asian populations (OR $0.46, \mathrm{p}=0.046$ ), but not in Caucasian populations (OR 0.75, $\mathrm{p}=0.120$ ). A further subgroup analysis by TBI grade showed that the APOE $\varepsilon 4$ allele was associated with poor prognosis in severe TBI (OR $0.43, p=0.020)$, but not for other grades (Table 2 ).

\section{APOE in Multiple Sclerosis}

Though studies from Italy ${ }^{60}$ and $\operatorname{Japan}^{50}$ did not show any association between $A P O E \varepsilon 4$ and progression of multiple sclerosis, a study from Austria (Enzinger et al. ${ }^{16}$ ) demonstrated a negative influence of $A P O E \varepsilon 4$ on brain volume, contributing to increasing brain atrophy in multiple sclerosis.

\section{$A P O E$ and Neuromuscular Disease}

The association of APOE polymorphism with peripheral nervous system diseases has been discussed in literature as well. However, the association, though significant, seems to be weaker than for CNS disease. ${ }^{4}$

\section{Diabetic Neuropathy}

In a study of 158 non-insulin-dependent diabetes patients from Japan, the prevalence of neuropathy was found to be greater in patients with $A P O E \varepsilon 4$ (39\%) than in patients with $A P O E \varepsilon 3(28 \%)$ or APOE $\varepsilon 2$ (23\%). Patients with $A P O E \& 4$ were also found to have an earlier onset of neuropathy as well as greater severity than patients without that allele. ${ }^{74}$

\section{Human Immunodeficiency Virus-Related Neuropathy}

Although patients with the APOE $\varepsilon 4$ allele were found to have more severe neuropathy after HIV, the association has not been thoroughly explored in the literature. ${ }^{11}$

\section{Amyotrophic Lateral Sclerosis}

Despite multiple studies, the role of APOE in the prognosis of amyotrophic lateral sclerosis (ALS) remains controversial. In one of the initial reports, Mui et al. ${ }^{47}$ suggested that age of onset and the duration of ALS did not correlate with $A P O E$ polymorphism status; however, that study's criteria for defining were later criticized. ${ }^{4} \mathrm{Al}$-Chalabi et al. noted that median survival was 35 months in patients with $A P O E \varepsilon 4$ and 49 months in patients without $A P O E \varepsilon 4$, but the difference was not statistically significant. ${ }^{2}$ Moulard et al. found that although the allele frequency did not differ significantly between patients with ALS and controls, patients with the APOE $\varepsilon 2 / \varepsilon 3$ genotype showed a significantly longer duration of the disease-median duration 51 months versus 28.5 for $A P O E \varepsilon 3 / \varepsilon 3$ and 27.5 for $A P O E \varepsilon 3 / \varepsilon 4$ ( $\mathrm{p}=0.001$ and $\mathrm{p}=0.02$, respectively). In the bulbar group, patients with the APOE $\varepsilon 4$ allele showed earlier onset of the disease. ${ }^{46}$ Similarly, Praline et al. ${ }^{55}$ found that the APOE \&4 allele was associated with an increased risk of bulbar-onset ALS in men. Nevertheless Siddique et al ${ }^{67}$ and Zetterberg et al.${ }^{85}$ found no significant relationship between $A P O E$ allele status and age of onset. In contrast, a study by Li et al. ${ }^{35}$ provided support for a protective role of APOE $\varepsilon 2$. This controversy is reflected in the recent meta-analysis by Govone et al. ${ }^{21}$ in which the $\varepsilon 4$ allele was not associated with a significantly increased disease risk of ALS.

\section{Guamanian ALS/Parkinsonism-Dementia Complex}

The available literature on the association of $A P O E$ with Guamanian ALS/parkinsonism-dementia complex is limited by a small sample size. Waring et al. did not find any difference in the distribution of $A P O E \varepsilon 4$ among patients and controls,$^{76}$ but they found that $A P O E \varepsilon 2$ had a protective role. Nevertheless, a recent study did not find any association. ${ }^{20}$

\section{Stroke \\ Cerebral Amyloid Angiopathy}

Sporadic cerebral amyloid angiopathy (CAA) is characterized by the deposition of $A \beta$ protein in small to medium-sized leptomeningeal and cortical blood vessels. ${ }^{41} \mathrm{~A}$ minority of patients may develop single or multiple CAArelated hemorrhages. $A P O E \& 4$ allele was found to increase $A \beta$ deposition in the cerebral vasculature, whereas $A P O E \varepsilon 2$ was associated with rupture of $\mathrm{A} \beta$-laden blood vessels and resulting hemorrhage. ${ }^{41}$ Greenberg et al. found that the age at first CAA hemorrhage was earlier in patients with $A P O E \varepsilon 2.22$ 
Ischemic Stroke, Intracerebral Hemorrhage, and Subarachnoid Hemorrhage

As with most of the other diseases, investigation of an association between $A P O E$ and ischemic stroke, intracerebral hemorrhage, and subarachnoid hemorrhage has produced varying results. In a study of stroke in a Japanese rural population, Kokubo et al..$^{32}$ found that, compared with individuals with the $A P O E \varepsilon 3 / \varepsilon 3$ genotype, $\varepsilon 2$ carriers had a 2-fold risk of cerebral infarction. The risk is greater for cortical infarction, but not for lacunar infarction. These individuals were also at risk for atherothrombosis and cardioembolism. Those with the APOE $\varepsilon 2 / \varepsilon 2$ genotype had an increased risk of intracerebral hemorrhage (ICH) as well. $A P O E$ \&4 carriers had a 2.5 -fold increased risk of subarachnoid hemorrhage (SAH). Individuals with the APOE $\varepsilon 3 / \varepsilon 4$ genotype showed a 2-fold increased risk of atherothrombosis and ICH. The association between $\varepsilon 2$ and stroke was accentuated in patients aged 70 years or older, but not in those aged 40-69 years. In a meta-analysis of 26 studies of ischemic stroke, 3 studies of $\mathrm{SAH}$, and 8 studies of $\mathrm{ICH}$, patients with the $A P O E \varepsilon 4$ allele were significantly more susceptible to ischemic stroke (OR 1.11) and SAH (OR 1.42) but not to ICH. Rather, APOE $\varepsilon 2$ was found to be associated with ICH (OR 1.32) (more strongly for lobar than for deeper hemorrhages). However the strength of association was poor. The association appeared stronger for Asian populations compared with white populations. ${ }^{70}$ However, a recent meta-analysis of 11 case-control studies with $1238 \mathrm{ICH}$ cases and 3575 controls concluded that ICH patients had a significantly higher frequency of the $A P O E$ $\varepsilon 4$ allele (OR 1.42, $\mathrm{p}<0.001)$, but there was no significant association between ICH and the APOE $\varepsilon 2$ allele. In the subgroup analysis by race, patients with ICH had a significantly higher frequency of the APOE $\varepsilon 4$ allele in Asian (p $<0.001)$ as well as Caucasian $(\mathrm{p}=0.009)$ groups. There was no significant relationship between the $A P O E$ \&2 allele and the risk of $\mathrm{ICH} .{ }^{86}$ The presence of $A P O E \varepsilon 4$ was found to increase the risk of delayed ischemic neurological deficit in one study. ${ }^{33}$

\section{Other Cranial Diseases}

An association has been sought in several other diseases as well. In a small sample of patients with inclusion body myositis, $A P O E \varepsilon 4$ was found to be overrepresented and $A P O E$ \&2 was found to be underrepresented in comparison with frequencies in controls. ${ }^{26}$ No association was found in patients with familial amyloidic polyneuropathy. ${ }^{59}$ A meta-analysis of 22 studies of sporadic PD suggested an association with $A P O E \varepsilon 2$ rather than $A P O E \varepsilon 4$ (OR 1.2 and 0.99 , respectively). ${ }^{27}$ The $A P O E \varepsilon 4$ allele (OR 1.41) was associated with an increased risk of CreutzfeldJakob disease (CJD), and APOE $\varepsilon 3$ (OR 0.81) tended to be protective against CJD in another meta-analysis of 11 case-control studies. ${ }^{77} \mathrm{~A}$ meta-analysis of $A P O E$ in schizophrenia did not support a major role for the $A P O E$ gene in that disease as a whole, but male patients with $A P O E$ $\varepsilon 2$ were found to have an increased risk of schizophrenia (although the increase was not statistically significant). ${ }^{63}$

\section{Spinal Cord Injury and Degeneration}

Surprisingly, there have been fewer studies of $A P O E$ polymorphism in spinal cord injury and degenerative conditions of the cord than in cranial disease, although the injury mechanism remains same. In patients with cervical cord injuries, the $A P O E \& 4$ allele was associated with differences in neurological recovery and longer length of stay in a rehabilitation facility. ${ }^{29}$ Setzer et al. found that $A P O E$ $\varepsilon 4$ was more prevalent in patients with cervical myelopathy than in controls. ${ }^{65}$ In an extension of this study they found that the presence of $A P O E \& 4$ was an independent predictor of poor outcome after anterior decompression surgery in these patients. ${ }^{66}$

\section{Comments}

Since the initial reports of the association of $A P O E$ with various neurological diseases, much enthusiasm has been noted among the researchers in last 3 decades. Although the initial reports almost universally suggested that $A P O E$ $\varepsilon 4$ was associated with poorer outcome, subsequent studies have proven that the association is not straightforward. $A P O E \varepsilon 2$, which may be protective for $\mathrm{AD}$, is found to be associated with increased risk for other diseases like amyloid angiopathy-related hemorrhage and sporadic PD. The literature shows plenty of reports in which $A P O E$ polymorphism did not have any correlation with pathogenesis and outcome, despite the fact that negative reports are generally less published. Though there is tantalizing evidence of an association with $A P O E$ polymorphism in AD studies and in most of the studies of TBI, similar conclusions cannot be drawn for other diseases. Also, the extent of association with specific diseases varied from study to study. This discrepancy is hard to understand, especially when there are similarities between the cellular pathologies of the various diseases. One possible explanation for this ambiguity may be small sample sizes and lack of proper control groups. The ethnic variation of different populations in the world may also explain some findings. The results show some variation according to age and gender as well. As $A P O E$ has been found to affect many nonneurological diseases like hypertension, coronary artery disease, and diabetes mellitus, nonadjustment for these comorbidities led to methodological flaws in much of the available literature. Again, the role of genetic and epigenetic factors affecting $A P O E$ expression (as, for example, in the above-mentioned studies of promoter regions of $A P O E$ for AD) has not been studied extensively for diseases other than AD. Finally, a continuous search for other genetic markers and knowledge of interaction between genetic markers may give new insight into our understanding of the pathogenesis of these diseases.

\section{Conclusions}

In summary, the understanding of the role of $A P O E$ may be still preliminary for diseases other than AD. Further studies should involve larger sample sizes, rigid and objective definitions of the diseases being studied, and proper at-risk and disease-free control groups to minimize methodological flaws. An ongoing search for other genes involved in the variability of $A P O E$ expression and study of the newer genes in relation to established factors and periodic meta-analyses in various diseases are needed to solidify this relationship. ${ }^{4}$ 


\section{References}

1. Aggerbeck LP, Wetterau JR, Weisgraber KH, Wu CS, Lindgren FT: Human apolipoprotein E3 in aqueous solution. II. Properties of the amino- and carboxyl-terminal domains. J Biol Chem 263:6249-6258, 1988

2. Al-Chalabi A, Enayat ZE, Bakker MC, Sham PC, Ball DM, Shaw CE, et al: Association of apolipoprotein E epsilon 4 allele with bulbar-onset motor neuron disease. Lancet 347:159-160, 1996

3. Arendt T, Schindler C, Brückner MK, Eschrich K, Bigl V, Zedlick D, et al: Plastic neuronal remodeling is impaired in patients with Alzheimer's disease carrying apolipoprotein $\varepsilon 4$ allele. J Neurosci 17:516-529, 1997

4. Bedlack RS, Strittmatter WJ, Morgenlander JC: Apolipoprotein $\mathrm{E}$ and neuromuscular disease: a critical review of the literature. Arch Neurol 57:1561-1565, 2000

5. Bellosta S, Nathan BP, Orth M, Dong LM, Mahley RW, Pitas RE: Stable expression and secretion of apolipoproteins E3 and E4 in mouse neuroblastoma cells produces differential effects on neurite outgrowth. J Biol Chem 270:27063-27071, 1995

6. Brat DJ, Gearing M, Goldthwaite PT, Wainer BH, Burger PC: Tau-associated neuropathology in ganglion cell tumours increases with patient age but appears unrelated to ApoE genotype. Neuropathol Appl Neurobiol 27:197-205, 2001

7. Brichtová E, Kozák L: Apolipoprotein E genotype and traumatic brain injury in children-association with neurological outcome. Childs Nerv Syst 24:349-356, 2008

8. Caselli RJ, Osborne D, Reiman EM, Hentz JG, Barbieri CJ, Saunders AM, et al: Preclinical cognitive decline in late middle-aged asymptomatic apolipoprotein E-e4/4 homozygotes: a replication study. J Neurol Sci 189:93-98, 2001

9. Chamelian L, Reis M, Feinstein A: Six-month recovery from mild to moderate traumatic brain injury: the role of APOE- $\varepsilon 4$ allele. Brain 127:2621-2628, 2004

10. Corbo RM, Scacchi R: Apolipoprotein E (APOE) allele distribution in the world. Is APOE*4 a 'thrifty' allele? Ann Hum Genet 63:301-310, 1999

11. Corder EH, Robertson K, Lannfelt L, Bogdanovic N, Eggertsen G, Wilkins J, et al: HIV-infected subjects with the E4 allele for APOE have excess dementia and peripheral neuropathy. Nat Med 4:1182-1184, 1998

12. Corder EH, Saunders AM, Strittmatter WJ, Schmechel DE, Gaskell PC, Small GW, et al: Gene dose of apolipoprotein E type 4 allele and the risk of Alzheimer's disease in late onset families. Science 261:921-923, 1993

13. Deary IJ, Whiteman MC, Pattie A, Starr JM, Hayward C, Wright AF, et al: Cognitive change and the APOE $\varepsilon 4$ allele. Nature 418:932, 2002

14. Diaz-Arrastia R, Gong Y, Fair S, Scott KD, Garcia MC, Carlile MC, et al: Increased risk of late posttraumatic seizures associated with inheritance of APOE $\varepsilon 4$ allele. Arch Neurol 60:818-822, 2003

15. Egensperger R, Bancher C, Kösel S, Jellinger K, Mehraein P, Graeber MB: The apolipoprotein E \&4 allele in Parkinson's disease with Alzheimer lesions. Biochem Biophys Res Commun 224:484-486, 1996

16. Enzinger C, Ropele S, Smith S, Strasser-Fuchs S, Poltrum B, Schmidt H, et al: Accelerated evolution of brain atrophy and "black holes" in MS patients with APOE- 4 4. Ann Neurol 55:563-569, 2004

17. Farrer LA, Cupples LA, Haines JL, Hyman B, Kukull WA, Mayeux R, et al: Effects of age, sex, and ethnicity on the association between apolipoprotein E genotype and Alzheimer disease. A meta-analysis. JAMA 278:1349-1356, 1997

18. Friedman G, Froom P, Sazbon L, Grinblatt I, Shochina M, Tsenter J, et al: Apolipoprotein E- $\varepsilon 4$ genotype predicts a poor outcome in survivors of traumatic brain injury. Neurology 52:244-248, 1999
19. Galasko D, Chang L, Motter R, Clark CM, Kaye J, Knopman $D$, et al: High cerebrospinal fluid tau and low amyloid $\beta 42$ levels in the clinical diagnosis of Alzheimer disease and relation to apolipoprotein E genotype. Arch Neurol 55:937-945, 1998

20. Galasko D, Salmon D, Gamst A, Olichney J, Thal LJ, Silbert $\mathrm{L}$, et al: Prevalence of dementia in Chamorros on Guam: relationship to age, gender, education, and APOE. Neurology 68:1772-1781, 2007

21. Govone F, Vacca A, Rubino E, Gai A, Boschi S, Gentile S, et al: Lack of association between APOE gene polymorphisms and amyotrophic lateral sclerosis: a comprehensive metaanalysis. Amyotroph Lateral Scler Frontotemporal Degener 15:551-556, 2014

22. Greenberg SM, Vonsattel JP, Segal AZ, Chiu RI, Clatworthy AE, Liao A, et al: Association of apolipoprotein E epsilon2 and vasculopathy in cerebral amyloid angiopathy. Neurology 50:961-965, 1998

23. Guo Z, Cupples LA, Kurz A, Auerbach SH, Volicer L, Chui $\mathrm{H}$, et al: Head injury and the risk of AD in the MIRAGE study. Neurology 54:1316-1323, 2000

24. Han SD, Drake AI, Cessante LM, Jak AJ, Houston WS, Delis DC, et al: Apolipoprotein E and traumatic brain injury in a military population: evidence of a neuropsychological compensatory mechanism? J Neurol Neurosurg Psychiatry 78:1103-1108, 2007

25. Hardy J, Crook R, Prihar G, Roberts G, Raghavan R, Perry $\mathrm{R}$ : Senile dementia of the Lewy body type has an apolipoprotein $\mathrm{E} \varepsilon 4$ allele frequency intermediate between controls and Alzheimer's disease. Neurosci Lett 182:1-2, 1994

26. Harrington CR, Anderson JR, Chan KK: Apolipoprotein E type $\varepsilon 4$ allele frequency is not increased in patients with sporadic inclusion-body myositis. Neurosci Lett 183:35-38, 1995

27. Huang X, Chen PC, Poole C: APOE-ع2 allele associated with higher prevalence of sporadic Parkinson disease. Neurology 62:2198-2202, 2004

28. Itzhaki RF, Dobson CB, Shipley SJ, Wozniak MA: The role of viruses and of APOE in dementia. Ann N Y Acad Sci 1019:15-18, 2004

29. Jha A, Lammertse DP, Coll JR, Charlifue S, Coughlin CT, Whiteneck GG, et al: Apolipoprotein E $\varepsilon 4$ allele and outcomes of traumatic spinal cord injury. J Spinal Cord Med 31:171-176, 2008

30. Jordan BD, Relkin NR, Ravdin LD, Jacobs AR, Bennett A, Gandy S: Apolipoprotein E $\varepsilon 4$ associated with chronic traumatic brain injury in boxing. JAMA 278:136-140, 1997

31. Kehoe P, Krawczak M, Harper PS, Owen MJ, Jones AL: Age of onset in Huntington disease: sex specific influence of apolipoprotein E genotype and normal CAG repeat length. J Med Genet 36:108-111, 1999

32. Kokubo Y, Chowdhury AH, Date C, Yokoyama T, Sobue H, Tanaka H: Age-dependent association of apolipoprotein $\mathrm{E}$ genotypes with stroke subtypes in a Japanese rural population. Stroke 31:1299-1306, 2000

33. Lanterna LA, Rigoldi M, Tredici G, Biroli F, Cesana C, Gaini SM, et al: APOE influences vasospasm and cognition of noncomatose patients with subarachnoid hemorrhage. Neurology 64:1238-1244, 2005

34. Laws SM, Hone E, Gandy S, Martins RN: Expanding the association between the APOE gene and the risk of Alzheimer's disease: possible roles for APOE promoter polymorphisms and alterations in APOE transcription. $\mathbf{J}$ Neurochem 84:1215-1236, 2003

35. Li YJ, Pericak-Vance MA, Haines JL, Siddique N, McKennaYasek D, Hung WY, et al: Apolipoprotein E is associated with age at onset of amyotrophic lateral sclerosis. Neurogenetics 5:209-213, 2004

36. Liu Y, Yu JT, Wang HF, Han PR, Tan CC, Wang C, et al: 
APOE genotype and neuroimaging markers of Alzheimer's disease: systematic review and meta-analysis. J Neurol Neurosurg Psychiatry 86:127-134, 2015

37. Luukinen H, Viramo P, Herala M, Kervinen K, Kesäniemi YA, Savola O, et al: Fall-related brain injuries and the risk of dementia in elderly people: a population-based study. Eur J Neurol 12:86-92, 2005

38. Mahley RW: Apolipoprotein E: cholesterol transport protein with expanding role in cell biology. Science 240:622-630, 1988

39. Mahley RW, Huang Y: Apolipoprotein (apo) E4 and Alzheimer's disease: unique conformational and biophysical properties of apoE4 can modulate neuropathology. Acta Neurol Scand Suppl 185:8-14, 2006

40. Martins RN, Clarnette R, Fisher C, Broe GA, Brooks WS, Montgomery P, et al: ApoE genotypes in Australia: roles in early and late onset Alzheimer's disease and Down's syndrome. Neuroreport 6:1513-1516, 1995

41. McCarron MO, Nicoll JA, Ironside JW, Love S, Alberts MJ, Bone I: Cerebral amyloid angiopathy-related hemorrhage. Interaction of APOE $\varepsilon 2$ with putative clinical risk factors. Stroke 30:1643-1646, 1999

42. Mehta KM, Ott A, Kalmijn S, Slooter AJ, van Duijn CM, Hofman A, et al: Head trauma and risk of dementia and Alzheimer's disease: The Rotterdam Study. Neurology 53:1959-1962, 1999

43. Morris CM, Massey HM, Benjamin R, Leake A, Broadbent C, Griffiths M, et al: Molecular biology of APO E alleles in Alzheimer's and non-Alzheimer's dementias. J Neural Transm Suppl 47:205-218, 1996

44. Morrow JA, Hatters DM, Lu B, Hochtl P, Oberg KA, Rupp $\mathrm{B}$, et al: Apolipoprotein E4 forms a molten globule. A potential basis for its association with disease. J Biol Chem 277:50380-50385, 2002

45. Morrow JA, Segall ML, Lund-Katz S, Phillips MC, Knapp M, Rupp B, et al: Differences in stability among the human apolipoprotein $\mathrm{E}$ isoforms determined by the amino-terminal domain. Biochemistry 39:11657-11666, 2000

46. Moulard B, Sefiani A, Laamri A, Malafosse A, Camu W: Apolipoprotein E genotyping in sporadic amyotrophic lateral sclerosis: evidence for a major influence on the clinical presentation and prognosis. J Neurol Sci 139 Suppl:34-37, 1996

47. Mui S, Rebeck GW, McKenna-Yasek D, Hyman BT, Brown RH Jr: Apolipoprotein E $\varepsilon 4$ allele is not associated with earlier age at onset in amyotrophic lateral sclerosis. Ann Neurol 38:460-463, 1995

48. Nathan BP, Bellosta S, Sanan DA, Weisgraber KH, Mahley RW, Pitas RE: Differential effects of apolipoproteins E3 and E4 on neuronal growth in vitro. Science 264:850-852, 1994

49. Nathoo N, Chetry R, van Dellen JR, Connolly C, Naidoo R: Apolipoprotein E polymorphism and outcome after closed traumatic brain injury: influence of ethnic and regional differences. J Neurosurg 98:302-306, 2003

50. Niino M, Kikuchi S, Fukazawa T, Yabe I, Tashiro K: Polymorphisms of apolipoprotein E and Japanese patients with multiple sclerosis. Mult Scler 9:382-386, 2003

51. Noguchi S, Murakami K, Yamada N: Apolipoprotein E genotype and Alzheimer's disease. Lancet 342:737, 1993

52. Olichney JM, Hansen LA, Galasko D, Saitoh T, Hofstetter CR, Katzman R, et al: The apolipoprotein E epsilon 4 allele is associated with increased neuritic plaques and cerebral amyloid angiopathy in Alzheimer's disease and Lewy body variant. Neurology 47:190-196, 1996

53. Poirier J: Apolipoprotein E: a pharmacogenetic target for the treatment of Alzheimer's disease. Mol Diagn 4:335-341, 1999

54. Poirier J, Davignon J, Bouthillier D, Kogan S, Bertrand P, Gauthier S: Apolipoprotein E polymorphism and Alzheimer's disease. Lancet 342:697-699, 1993
55. Praline J, Blasco H, Vourc'h P, Garrigue MA, Gordon PH, Camu W, et al: APOE $\varepsilon 4$ allele is associated with an increased risk of bulbar-onset amyotrophic lateral sclerosis in men. Eur J Neurol 18:1046-1052, 2011

56. Pruthi N, Chandramouli BA, Kuttappa TB, Rao SL, Subbakrishna DK, Abraham MP, et al: Apolipoprotein E polymorphism and outcome after mild to moderate traumatic brain injury: a study of patient population in India. Neurol India 58:264-269, 2010

57. Roses AD: Apolipoprotein E genotyping in the differential diagnosis, not prediction, of Alzheimer's disease. Ann Neurol 38:6-14, 1995

58. Sadigh-Eteghad S, Talebi M, Farhoudi M: Association of apolipoprotein E epsilon 4 allele with sporadic late onset Alzheimer's disease. A meta-analysis. Neurosciences (Riyadh) 17:321-326, 2012

59. Saunders AM, Schmader K, Breitner JC, Benson MD, Brown WT, Goldfarb L, et al: Apolipoprotein E \&4 allele distributions in late-onset Alzheimer's disease and in other amyloidforming diseases. Lancet 342:710-711, 1993

60. Savettieri G, Andreoli V, Bonavita S, Cittadella R, Caltagirone $\mathrm{C}$, Fazio $\mathrm{MC}$, et al: Apolipoprotein $\mathrm{E}$ genotype does not influence the progression of multiple sclerosis. J Neurol 250:1094-1098, 2003

61. Schilling S, DeStefano AL, Sachdev PS, Choi SH, Mather KA, DeCarli CD, et al: APOE genotype and MRI markers of cerebrovascular disease: systematic review and meta-analysis. Neurology 81:292-300, 2013

62. Schmechel DE, Saunders AM, Strittmatter WJ, Crain BJ, Hulette CM, Joo SH, et al: Increased amyloid beta-peptide deposition in cerebral cortex as a consequence of apolipoprotein E genotype in late-onset Alzheimer disease. Proc Natl Acad Sci U S A 90:9649-9653, 1993

63. Schürhoff F, Krebs MO, Szöke A, Loze JY, Goldberger $\mathrm{C}$, Quignon V, et al: Apolipoprotein E in schizophrenia: a French association study and meta-analysis. Am J Med Genet B Neuropsychiatr Genet 119B:18-23, 2003

64. Seet WT, Mary Anne TJ, Yen TS: Apolipoprotein E genotyping in the Malay, Chinese and Indian ethnic groups in Malaysia-a study on the distribution of the different apoE alleles and genotypes. Clin Chim Acta 340:201-205, 2004

65. Setzer M, Hermann E, Seifert V, Marquardt G: Apolipoprotein $\mathrm{E}$ gene polymorphism and the risk of cervical myelopathy in patients with chronic spinal cord compression. Spine (Phila Pa 1976) 33:497-502, 2008

66. Setzer M, Vrionis FD, Hermann EJ, Seifert V, Marquardt G: Effect of apolipoprotein E genotype on the outcome after anterior cervical decompression and fusion in patients with cervical spondylotic myelopathy. J Neurosurg Spine 11:659-666, 2009

67. Siddique T, Pericak-Vance MA, Caliendo J, Hong ST, Hung WY, Kaplan J, et al: Lack of association between apolipoprotein E genotype and sporadic amyotrophic lateral sclerosis. Neurogenetics 1:213-216, 1998

68. Siest G, Pillot T, Régis-Bailly A, Leininger-Muller B, Steinmetz J, Galteau MM, et al: Apolipoprotein E: an important gene and protein to follow in laboratory medicine. Clin Chem 41:1068-1086, 1995

69. Sorbi S, Nacmias B, Piacentini S, Repice A, Latorraca S, Forleo P, et al: ApoE as a prognostic factor for post-traumatic coma. Nat Med 1:852, 1995

70. Sudlow C, Martínez González NA, Kim J, Clark C: Does apolipoprotein $\mathrm{E}$ genotype influence the risk of ischemic stroke, intracerebral hemorrhage, or subarachnoid hemorrhage? Systematic review and meta-analyses of 31 studies among 5961 cases and 17,965 controls. Stroke 37:364-370, 2006

71. Takeda M, Martínez R, Kudo T, Tanaka T, Okochi M, Tagami S, et al: Apolipoprotein $\mathrm{E}$ and central nervous system 
disorders: reviews of clinical findings. Psychiatry Clin Neurosci 64:592-607, 2010

72. Tang MX, Maestre G, Tsai WY, Liu XH, Feng L, Chung WY, et al: Effect of age, ethnicity, and head injury on the association between APOE genotypes and Alzheimer's disease. Ann N Y Acad Sci 802:6-15, 1996

73. Teasdale GM, Murray GD, Nicoll JA: The association between APOE \&4, age and outcome after head injury: a prospective cohort study. Brain 128:2556-2561, 2005

74. Tsuzuki S, Murano T, Watanabe H, Itoh Y, Miyashita Y, Shirai K: [The examination of apoE phenotypes in diabetic patients with peripheral neuropathy.] Rinsho Byori 46:829833, 1998 (Jpn)

75. Verpillat P, Camuzat A, Hannequin D, Thomas-Anterion C, Puel M, Belliard S, et al: Apolipoprotein E gene in frontotemporal dementia: an association study and meta-analysis. Eur J Hum Genet 10:399-405, 2002

76. Waring SC, O'Brien PC, Kurland LT, Thibodeau SN, Tsai MS, Petersen RC, et al: Apolipoprotein E allele in Chamorros with amyotrophic lateral sclerosis/parkinsonism-dementia complex. Lancet 343:611, 1994

77. Wei Y, Tang Y, He W, Qu Z, Zeng J, Qin C: APOE gene polymorphisms and susceptibility to Creutzfeldt-Jakob disease. J Clin Neurosci 21:390-394, 2014

78. West HL, Rebeck GW, Hyman BT: Frequency of the apolipoprotein E $\varepsilon 2$ allele is diminished in sporadic Alzheimer disease. Neurosci Lett 175:46-48, 1994

79. Wetterau JR, Aggerbeck LP, Rall SC Jr, Weisgraber KH: Human apolipoprotein E3 in aqueous solution. I. Evidence for two structural domains. J Biol Chem 263:6240-6248, 1988

80. Xin XY, Ding JQ, Chen SD: Apolipoprotein E promoter polymorphisms and risk of Alzheimer's disease: evidence from meta-analysis. J Alzheimers Dis 19:1283-1294, 2010

81. Yamanouchi Y, Arinami T, Tsuchiya S, Miyazaki R, Takaki H, Takano T, et al: Apolipoprotein E5 and E7 in apparently healthy Japanese males: frequencies and relation to plasma lipid levels. Jpn J Hum Genet 39:315-324, 1994

82. Yang DS, Small DH, Seydel U, Smith JD, Hallmayer J, Gandy SE, et al: Apolipoprotein E promotes the binding and uptake of beta-amyloid into Chinese hamster ovary cells in an isoform-specific manner. Neuroscience 90:1217-1226, 1999

83. Yang DS, Smith JD, Zhou Z, Gandy SE, Martins RN: Characterization of the binding of amyloid-beta peptide to cell culture-derived native apolipoprotein E2, E3, and E4 isoforms and to isoforms from human plasma. J Neurochem 68:721-725, 1997

84. Zeng S, Jiang JX, Xu MH, Xu LS, Shen GJ, Zhang AQ, et al: Prognostic value of apolipoprotein E $\varepsilon 4$ allele in patients with traumatic brain injury: a meta-analysis and meta-regression. Genet Test Mol Biomarkers 18:202-210, 2014

85. Zetterberg H, Jacobsson J, Rosengren L, Blennow K, Andersen PM: Association of APOE with age at onset of sporadic amyotrophic lateral sclerosis. J Neurol Sci 273:67-69, 2008

86. Zhang R, Wang X, Tang Z, Liu J, Yang S, Zhang Y, et al: Apolipoprotein $\mathrm{E}$ gene polymorphism and the risk of intracerebral hemorrhage: a meta-analysis of epidemiologic studies. Lipids Health Dis 13:47, 2014

87. Zhou W, Xu D, Peng X, Zhang Q, Jia J, Crutcher KA: Metaanalysis of APOE4 allele and outcome after traumatic brain injury. J Neurotrauma 25:279-290, 2008

\section{Disclosure}

The authors report no conflict of interest concerning the materials or methods used in this study or the findings specified in this paper.

\section{Author Contributions}

Conception and design: Nanda, Maiti, Konar, Bir. Acquisition of data: Maiti, Konar, Bir. Analysis and interpretation of data: Maiti, Konar, Bir. Drafting the article: Maiti, Konar, Bir. Critically revising the article: Nanda, Maiti, Konar, Bir. Reviewed submitted version of manuscript: Maiti, Konar, Bir, Kalakoti, Bollam. Administrative/technical/material support: Nanda.

\section{Correspondence}

Anil Nanda, Department of Neurosurgery, LSU Health Shreveport, 1501 Kings Hwy., Shreveport, LA 71130-3932. email: ananda@1suhsc.edu. 